\title{
Editorial
}

\section{Journal of Biology celebrates its fifth anniversary}

Published: 29 June 2007

Journal of Biology 2007, 6:5

The electronic version of this article is the complete one and can be found online at http://jbiol.com/content/6/3/5

(c) 2007 BioMed Central Ltd
Five years ago this month, Journal of Biology was launched under the guidance of Editor-in-Chief Martin Raff and Editor Theodora Bloom as the premier biology journal of the open access publisher BioMed Central, the publisher of Genome Biology and the $B M C$ series of journals. As we celebrate Journal of Biology's birthday, we take this opportunity to reflect on the first five years during which the journal has published articles of exceptional interest across the full spectrum of biology.

In its first year of publication, Journal of Biology aimed very high and although it considered many manuscripts, it published only six original research articles of remarkably broad interest and importance, each accompanied by a minireview and a research news article that put the work in context for a broader audience. That these were truly exceptional articles is not in doubt: the first, by Paul Spellman and Gerry Rubin (Evidence for large domains of similarly expressed genes in the Drosophila genome [1]) has been accessed more than 28,000 times from our site alone. Like all Journal of Biology content it is also freely available from PubMed Central and other mirror sites, so we do not know how many people have downloaded it in total. According to the Institute for Scientific Information (ISI) [2], it has been cited over 190 times. Please see Box 1 for a selection of research articles and the number of times they have been cited and accessed. Publishing on average only every two months has its perils, however: both authors and readers told us that they'd be happier to see a journal that wasn't so very selective and published more often. The journal is now planning to build on its success in publishing high-quality articles and is striving to increase the rate of publication, while maintaining a very high standard.

"(Our article) has already been cited at least 8 times in the first 4 months after publication."

Dario Alessi University of Dundee

Looking back, it is very gratifying to see that the articles Journal of Biology has published cover the breadth of biology and come from labs around the world. Articles range from animal studies such as the hydrodynamics of dolphin drafting by Daniel Weihs [3] and the determinants of insect size by Frederik Nijhout et al. [4] to cellular and molecular level studies, including work from the groups of Martin Raff [5], Michael Hengartner [6] and Claude Lechene [7]. The journal's content also includes the most cutting edge work in systems biology and genomics $[1,8,9]$.

By virtue of their age more recent articles have yet to be highly cited, but are actively downloaded. For example, an article by Mark Noble and colleagues provided evidence that brain cells are susceptible to chemotherapy [10]; the article has been downloaded more than 5,000 times from the Journal of Biology site with a flurry of media interest.

Of course, for many authors, readers and institutions there is one measure that matters above all others in evaluating a journal: the impact factor, as determined by The Thomson Corporation (ISI). Editors tend to have an inconsistent response to impact factors. On one hand, we know that they are very crude measures of a journal's quality, subject to many unpredictable criteria [11] and, by their nature are a couple of years out of date by the time they appear [12]. On the other hand, we know how much they matter to authors and readers, not least because of a perception that hiring and funding committees rely on them. With this in mind, it is unfortunate that the impressive citation rate and number of downloads of Journal of Biology articles have yet to translate into an official impact factor - although the citation data are there for all to see [2]. This is because ISI has not officially started tracking the journal (in order to be considered for tracking by ISI, a journal is evaluated on numerous variables [12]). Regrettably, this selectivity on the part of ISI conceals the success of new journals. A case in point is Genome Biology, the sister journal of Journal of Biology, 


\section{Box I}

A selection of citation and access data for Journal of Biology articles.

Article

Hawley SA, Boudeau J, Reid JL, Mustard KJ, Udd L, Mäkelä TP, Alessi DR, Hardie G:

Complexes between the LKB1 tumor suppressor, STRAD $\alpha / \beta$ and $M O 25 \alpha / \beta$ are

upstream kinases in the AMP-activated protein kinase cascade.

J Biol 2003, 2:28

Spellman PT, Rubin GM:

28,000

195

Evidence for large domains of similarly expressed genes in the Drosophila genome.

J Biol 2002, 1:5

Kiger AA, Baum B, Jones S, Jones MR, Coulson A, Echeverri C, Perrimon N:

A functional genomic analysis of cell morphology using RNA interference.

J Biol 2003, 2:27

Frank-Kamenetsky M, Zhang XM, Bottega S, Guicherit O, Wichterle H, Dudek H,

Bumcrot D, Wang FY, Jones S, Shulok J, Rubin LL, Porter JA:

Small-molecule modulators of Hedgehog signaling: identification and

characterization of Smoothened agonists and antagonists.

J Biol 2002, 1:10

Okubo T, Hogan BL:

17,000

Hyperactive Wnt signaling changes the developmental potential of embryonic lung endoderm.

J Biol 2004, 3:11

Talbert PB, Bryson TD, Henikoff S:

Adaptive evolution of centromere proteins in plants and animals.

J Biol 2004, 3:18

Itoh K, Brott BK, Bae GU, Ratcliffe MJ, Sokol SY:

16,000

Nuclear localization is required for Dishvelled function in Wnt/ $\boldsymbol{\beta}$-catenin signaling.

J Biol 2005, 4:3

Gupta V, Parisi M, Sturgill D, Nuttall R, Doctolero M, Dudko OK, Malley JD,

10,000

Eastman PS, Oliver B:

Global analysis of X-chromosome dosage compensation.

J Biol 2006, 5:3

Reguly T, Breitkreutz A, Boucher L, Breitkreutz BJ, Hon GC, Myers CL, Parsons A,

Friesen H, Oughtred R, Tong A, Stark C, Ho Y, Botstein D, Andrews B, Boone C,

Troyanskya OG, Ideker T, Dolinski K, Batada NN, Tyers M:

Comprehensive curation and analysis of global interaction networks in

Saccharomyces cerevisiae.

J Biol 2006, 5:11

Ittner LM, Wurdak H, Schwerdtfeger K, Kunz T, Ille F, Leveen P, Hjalt TA, Suter U,

62,000

6

Karlsson S, Hafezi F, Born W, Sommer L:

Compound developmental eye disorders following inactivation of TGF $\beta$ signalling in neural-crest stem cells.

J Biol 2005, 4:11 
Table I

\begin{tabular}{lcc} 
Comparison of $\mathbf{2 0 0 5}$ journal impact factors for general science and biology journals. \\
\hline Journal & Impact factor & Launch date \\
\hline Nature & 32.2 & 1869 \\
Science & 30.9 & 1880 \\
Cell & 29.4 & 1974 \\
PNAS & 14.5 & 1915 \\
Journal of Biology* & 20.1 (predicted) & 2002 \\
PLoS Biology* & 13.9 & 2003 \\
Genome Biology* & 9.7 & 1999 \\
BMC Biology* & 4.4 (predicted) & 2003 \\
\hline
\end{tabular}

* Open access. The predicted impact factor is based on the number of times that research articles published in 2003 and 2004 were cited in 2005.

which waited over three years to be tracked by ISI and last year received its first impact factor of 9.712 after six years of continuous publishing. A second sister journal, BMC Biology, the broad-interest journal of the $B M C$ series of journals, also waited three years to be accepted for tracking by ISI and expects its first impact factor in June 2008.

"Of all the journal staffs with whom I have interacted, the group at Journal of Biology was the best at publicizing the results in appropriate circles."

Wyeth W. Wasserman University of British Columbia

BioMed Central is working closely with ISI to ensure that Journal of Biology will become accepted for tracking. In the meantime, using information in the ISI Web of Knowledge Cited Reference Index, which includes the entire reference list of all tracked journals (and therefore includes citations of journals that are not themselves tracked) we have calculated the unofficial impact factor of Journal of Biology to be 20.1. This is based on the number of times that research articles published in 2003-2004 were cited in 2005. This unofficial impact factor compares favorably with those of other journals (Table 1) and would place Journal of Biology in the top tier of general biology journals covered by ISI.

Despite the lack of an official impact factor, Journal of Biology is committed to maximising the impact and visibility of the exceptional research it publishes. By adopting an open access approach and making all research articles, minireviews and associated commentary freely available online we ensure that the articles published in the journal achieve maximum visibility and impact. Our experience is consistent with recent findings demonstrating that open access articles are cited more quickly and frequently than non-open access articles published in the same journal [13].

From the feedback we have received from authors it is clear that they value the benefits of open access and the fairness and rapidity of peer review. Nevertheless, it is also the journal's editors who are responsible for the day-to-day running of the journal and who ensure its exceptional standards are maintained. Martin Raff guided Journal of Biology through the early years with invaluable input as Editor-in-Chief. Theodora Bloom, the Editor of Journal of Biology since it launched in June 2002, is now moving on to new challenges. Over the years, Theo has worked tirelessly for the journal while acting as the Editorial Director for Biology at BioMed Central. We are extremely grateful to Martin and Theo for steering the course of Journal of Biology during the exciting journey of the past five years.

"It was a pleasure working with you, and we are proud to have our paper published in $\mathrm{J}$ Biol. We are big fans of open access publishing, and will continue to help open access journals become leaders in scientific publication."

\section{Michael Hengartner Universität Zürich}

Open access publishing has made remarkable progress since Journal of Biology was launched and now far more high-quality research can be seen in many open access journals. In an exciting new development, Journal of Biology is now broadening its horizons to include coverage of articles published in its open access sister journals of the $B M C$ series [14], in particular $B M C$ Biology, and other journals published by BioMed Central. In this way, Journal of Biology will not only highlight its own research papers but also draw attention to the very best research across the open access titles.

Finally, don't forget that Journal of Biology is also closely linked in other ways to Genome Biology, BMC Biology and the specialist journals in the $B M C$ series of journals. This offers greater flexibility and choice to authors when deciding where to submit and ultimately publish their research. For example, if a manuscript does not meet the very high standards of Journal of Biology but is otherwise sound, it is possible to expedite publication in one of its sister journals without 
further peer review. The advantage of this approach is that it is fast - there is no need to begin the peer-review process once more. Similarly, manuscripts submitted to BMC Biology, the flagship journal of the $B M C$ series, may be offered the choice of publishing in Journal of Biology if the editors and referees find the work to be of exceptional interest to a broad audience. This coordination between journals is convenient to both authors and referees: peer review and the path to publication is as smooth as possible.

If you have views about how we should be working to ensure an open access future for biological publishing, we'd love to hear from you. If you agree that the qualities outlined here represent the future for scientific publishing, you can help to make it happen by submitting your next exciting piece of research to Journal of Biology.

Penelope Webb, Editor

Elizabeth Moylan, Deputy Editor

editorial@jbiol.com

\section{References}

I. Spellman PT, Rubin GM: Evidence for large domains of similarly expressed genes in the Drosophila genome. J Biol 2002, I:5.

2. Institute for Scientific Information (ISI) Web of Knowledge Cited Reference Index website

[http://portal.isiknowledge.com/portal. cgi? DestApp=WOS\&Func $=$ Frame\&Init $=$ Yes\&SID=SIB9Kk4gEK6h86ePEIo]

3. Weihs $D:$ The hydrodynamics of dolphin drafting. J Biol 2004, 3:8.

4. Nijhout HF, Davidowitz G, Roff DA: A quantitative analysis of the mechanism that controls body size in Manduca sexta J Biol 2006, 5:16.

5. Conlon I, Raff M: Differences in the way a mammalian cell and yeast cells coordinate cell growth and cell-cycle progression. J Biol 2003, 2:7.

6. Su CW, Tharin $S$, Jin $Y$, Wightman $B$, Spector M, Meili D, Tsung N, Rhiner C, Bourikas D, Stoeckli E, Garriga G, Horvitz HR, Hengartner MO: The short coiled-coil domain-containing protein UNC-69 cooperates with UNC-76 to regulate axonal outgrowth and normal presynaptic organization in Caenorhabditis elegans. J Biol 2006, 5:9.

7. Lechene C, Hillion F, McMahon G, Benson D, Kleinfeld AM, Kampf JP, Distel $D$, Luyten $Y$, Bonventre J, Hentschel D, Park KM, Ito S, Schwartz M, Benichou G, Slodzian G: High-resolution quantitative imaging of mammalian and bacterial cells using stable isotope mass spectrometry. J Biol 2006, 5:20
8. Lenhard B, Sandelin A, Mendoza L, Engström $P$, Jareborg $N$, Wasserman WW: Identification of conserved regulatory elements by comparative genome analysis. J Biol 2003, 2:13

9. Kiger $A A$, Baum $B$, Jones $S$, Jones $M R$, Coulson A, Echeverri C, Perrimon N: A functional genomic analysis of cell morphology using RNA interference. J Biol 2003, 2:27.

10. Dietrich J, Han R, Yang Y, MayerPröschel M, Noble M: CNS progenitor cells and oligodendrocytes are targets of chemotherapeutic agents in vitro and in vivo. Biol 2006, 5:22.

II. The PLoS Medicine Editors: The Impact Factor Game. It is time to find a better way to assess the scientific literature. PLoS Med 2006, 3:e29I

12. Cockerill MJ: Delayed impact: ISI's citation tracking choices are keeping scientists in the dark. BMC Bioinformatics 2004, 5:93.

13. Eysenbach G: Citation advantage of open access articles. PLoS Biol 2006, 4:el57.

14. The BMC series journals [http://www.biomedcentral.com/info/ authors/bmcseries] 